Etnográfica

Revista do Centro em Rede de Investigação em

Antropologia

vol. 22 (1) | 2018

Vol. $22(1)$

\title{
The emergence of transnational political spaces
}

A emergência dos espaços políticos transnacionais

\section{Stephanie Schütze}

\section{(2) OpenEdition \\ Journals}

\section{Electronic version}

URL: https://journals.openedition.org/etnografica/5182

DOI: 10.4000/etnografica.5182

ISSN: 2182-2891

\section{Publisher}

Centro em Rede de Investigação em Antropologia

\section{Printed version}

Date of publication: 1 February 2018

Number of pages: 131-148

ISSN: 0873-6561

\section{Electronic reference}

Stephanie Schütze, "The emergence of transnational political spaces", Etnográfica [Online], vol. 22 (1) 2018, Online since 17 May 2018, connection on 19 January 2022. URL: http://

journals.openedition.org/etnografica/5182 ; DOI: https://doi.org/10.4000/etnografica.5182

\section{(c) (i) (9)}

Etnográfica is licensed under a Creative Commons Attribution-NonCommercial 4.0 International License. 


\section{The emergence of transnational political spaces}

\section{Stephanie Schütze}

This article retraces the ways in which politically-engaged Mexican migrant organizations from Chicago have contributed to the emergence of transnational political spaces since the late 1990s. The results of the underlying broad ethnographic study in Chicago and the Mexican state of Michoacán contribute to an understanding of transnational political spaces, based on the interplay of cross-border arenas of multifaceted political action. Mexican migrant organizations interact with their home communities, government agencies on both sides of the border and US civic organizations in civic and institutional political arenas. The ethnographic analysis highlights case-specific characteristics of transnational political spaces that are central to a more extensive theoretical understanding of transnationalization processes: "the local" as network of social relationships; the development of agency; political action in and beyond nation-state structures; and the intertwining of multifaceted interaction and communication arenas.

KEYWORDS: political action, interaction and communication, Mexican migrant organizations, leadership.

A emergência dos espaços políticos transnacionais • Este artigo delineia como o envolvimento político das organizações de migrantes mexicanos em Chicago tem contribuído para o surgimento de espaços políticos transnacionais desde o final da década de 1990. Tem por base os resultados de um estudo etnográfico amplo em Chicago e no estado mexicano de Michoacán, que contribuem para a compreensão dos espaços políticos transnacionais, com base na interação de arenas transfronteiriças de ação política multifacetada. Organizações de migrantes mexicanos interagem com as suas comunidades de origem, agências governamentais de ambos os lados da fronteira e organizações cívicas dos EUA em arenas políticas cívicas e institucionais. Através da análise etnográfica, destacam-se as características específicas dos espaços políticos transnacionais, que são fundamentais para uma compreensão teórica mais ampla dos processos de transnacionalização: "o local" como rede de relações sociais; o desenvolvimento da agência; a ação política dentro e para além das estruturas do Estado-nação; e o entrelaçamento das arenas multifacetadas da interação e da comunicação.

PALAVRAS-CHAVE: ação política, interação e comunicação, organizações de migrantes mexicanos, liderança.

SCHÜTZE, Stephanie (st.schuetze@fu-berlin.de) - Freie Universität Berlin, Lateinamerika-Institut, Germany. 


\section{INTRODUCTION}

This article retraces the ways in which politically-engaged Mexican migrant organizations from Chicago have contributed to the emergence of transnational political spaces between their regions of origin in Mexico and their places of residence in the United States since the late 1990s. These activists interact with members from their home communities, with government agencies on both sides of the border and with other civic organizations in multifaceted socio-political, civic and institutional arenas. From the interplay of these cross-border arenas transnational political spaces emerge. The following article is based on a broad ethnographic investigation that I conducted in the state of Michoacán and in metropolitan Chicago and highlights the study's findings on the emergence of transnational political spaces (Schütze 2016).

On the one hand, the article examines the emergence of transnational political spaces in the city of Chicago and its surrounding areas. Chicago was chosen as a research site because it has been a stronghold of Mexican migrant political participation in recent years. Before that, Los Angeles had been the stronghold of political activism of Mexican migrants ever since the Chicano movement of the 1960s. In a special section of the journal Latino Studies also including contributions from Xóchitl Bada (2013) and Judith Boruchoff (2013a, 2013b), I have pointed out the virtually unexplored role of Chicago as a new political center of Mexican migrant organizations (Schütze 2013). The panorama of Chicago's Mexican migrant organizations is broad: it ranges from civil society organizations (hometown associations) and chapters of Mexican political parties to institutions of the Mexican government. ${ }^{1}$ Beyond their Mexico-centered political activities, migrant organizations have also increasingly addressed the US public sphere in recent years. Ever since the first marches for comprehensive immigration reform, in 2006, Chicago has become a center of Mexican migrant political activity in the United States (Flores-González and Pallares 2010).

On the other hand, I analyze the relationships of the Chicago Mexican migrant groups with their communities of origin in Michoacán, which was chosen as a research site because it is one of the Mexican states most affected by migration to the United States. Today, between 30 and 60 per cent of the original population of their communities of origin live abroad; 13 per cent of all households in Michoacán have at least one member living as a migrant in the United States (López Castro 2003: 19). In Chicago, migrants from Michoacán first organized in clubs (hometown associations) of their communities of origin. The first Michoacano hometown association from Ciudad Hidalgo was

I In the 1990s the Partido Revolucionario Institucional (PRI), the Partido de la Revolución Democrática (PRD), and the Partido de Acción Nacional (PAN) began to organize local groups of affiliates among the Mexican migrant population of the US in the state of Illinois. 
founded in the 1970s and emerged from the soccer club Deportivo Taximaroa (Bada 2008: 99). But it was not until the 1990s that seven other hometown associations emerged and together founded the Federación de Clubes Michoacanos en Illinois (Fedecmi) to coordinate their work as an umbrella organization. Today about 43 hometown associations, each with a membership of 20 to 300 families, belong to the federation. Fedecmi has developed into the most publicly active federation of Mexican migrants in recent years. In 2004 Casa Michoacán was inaugurated as the seat of Fedecmi in Chicago's Pilsen neighborhood with help from the government of Michoacán.

In Michoacán, I interviewed 23 persons, the majority from three communities - Tarecuato, Acuitzio del Canje and Francisco Villa - that are involved in transnational projects at the local and the municipal levels. In Chicago, I interviewed 22 leading activists of Mexican migrant organizations. In order to capture the spectrum of migrant transnational participation in Chicago, I interviewed members of the hometown associations of the three communities in Michoacán, then I interviewed members of the local groups of the three major Mexican political parties, and finally leaders from other Mexican organizations in close contact with Fedecmi, such as Durango Unido and the Federación de Guerrerenses Radicados en Chicago. The majority of the interviewees in Chicago and Michoacán were men (8 women, 37 men). Previous studies of gender relations in Mexican organizations in the US indicate that Chicago is not an exception; they confirm male domination, especially with respect to hometown associations (Goldring 2001; Zamudio Grav 2005).

In the subsequent parts of the article, I first present my theoretical approach to the understanding of political processes in transnational spaces. Then I discuss the following characteristics of the emergence of transnational political spaces in more detail: first, "the local" as a network of social relationships; second, the development of agency; third, political action in and beyond nationstate structures; and fourth, the intertwining of multifaceted interaction and communication arenas.

\section{UNDERSTANDING POLITICAL PROCESSES IN TRANSNATIONAL SPACES}

To understand political processes in transnational spaces, I have systematically linked perspectives from transnational studies with research approaches from classical political anthropology. First, I refer to the symbolic school of anthropology that defines "the political" as decision-making and negotiation processes that imply power struggles and are at the same time collective and public (Swartz, Turner and Tuden 1966). Second, I relate to research on transnational migration, according to which transnational spaces are created by the permanent cross-border practices of social actors or communities and their relationship networks (Basch, Glick Schiller and Szanton Blanc 1994; Faist 
2006; Smith and Guarnizo 1998; Levitt and Glick Schiller 2004; Pries 1996, 2010; Vertovec 2009; and many others). I therefore analyze transnational political spaces as spheres in which communication takes place, community concerns are negotiated and decisions are made that link communities across the US-Mexican border because political spaces emerge on the basis of social relations between members of Chicago's migrant organizations and actors from Mexican communities.

Recent research on the political dimension of migration between Mexico and the United States has usually separated political and civic engagement: there are studies on migrant civic organizations, as in hometown associations (Bada 2008; Escala Rabadán 2005; Moctezuma Longoria 2003) and binational organizations (Brooks and Fox 2002; Rivera-Salgado 2002; Velasco Ortiz 2008); furthermore, there are studies on the movement for political rights, such as the fight for the right to vote in Mexico (Badillo Moreno 2004; Calderón Chelius 2003, 2011) and the movement for comprehensive immigration legislation in the United States (Bada, Fox and Seele 2006). Yet my case study shows that the transnationalization of political action is situated both outside and within political and institutional structures and processes (such as political parties, elections, government bodies).

The Mexican migrant activists I interviewed interact on different - nationstate and sub-national - levels in two countries and simultaneously transcend them. On the Mexican side, they interact with government bodies at the community, municipality, state (Michoacán) and federal levels. On the US side, they interact with government bodies at city (Chicago), county (Cook County), state (Illinois) and federal levels. The interviewees themselves differentiate "institutional politics" (party and government policy) from their own mostly voluntary engagement, which they consciously do not call political, but trabajo comunitario (work for a common good). In fact, however, their engagement moves in both civic (hometown associations and federation) and institutional-political contexts.

To understand the multifaceted political action of migrants, I use the concept of arena as a methodological and theoretical tool to analyze the emergence of transnational political spaces. I understand political spaces as relatively broad areas of political activities, while arenas are smaller spheres within these broad areas (cf. Lewellen 2003; Khagram and Levitt 2008). Arenas are understood as concrete places of representation and simultaneously as communication contexts (Strauss 1993; Turner 1974). My empirical study in Chicago and Michoacán contributes to an understanding of transnational political spaces, based on collective and personal connections of multifaceted local arenas of political action. Through this analysis, case-specific characteristics of transnational political spaces have emerged that are central to a more extensive theoretical understanding of such transnationalization processes: "the local" 
as network of social relationships; political action in and beyond nation-state structures; the development of agency; and the intertwining of multifaceted interaction and communication arenas.

\section{"The local" as network of social relationships}

The political interaction and communication arenas, which members of migrant organizations in Chicago have established with actors from their home communities in Michoacán, politicians and civic organizations, first emerge in local places, namely in Chicago neighborhoods (where the seats of the federations are located) and the communities of origin in Mexico. Earlier studies have highlighted the central importance of "the local" as a basic characteristic for the design of the transnational political spaces (Smith and Guarnizo 1998; Appadurai 1996; Goldring 1998). At first this statement seems contradictory since transnationalization as a cross-border phenomenon is automatically connected to the deterritorialization of social structures. But it turns out that long-term cross-border interaction and communication usually do not take place in free-floating structures, but are carried out by specific actors at specific locations and within clearly defined organizational forms (Smith and Guarnizo 1998: 11 ).

In her seminal work about hometown organizations, Luin Goldring expresses this ambiguity by stating that Mexican migrants "tend to continue to orient their lives in part around their place of origin, maintaining transnational spaces and multiple identities" (Goldring 1998: 167). Therefore, the establishment of hometown associations can be seen as an institutional expression of transnational communities, as also expressed in their naming, for example "Club Francisco Villa en Chicago, Illinois." In Chicago, the first hometown associations were founded as early as the 1970s; however, their numbers have multiplied since the 1990s. Initially, hometown associations emerged as associations of people from the same local community in Mexico to continue cultural practices in migration and to support each other in everyday life. Over time their activities increasingly began to focus on the organization of collective support projects for the communities of origin.

In the analysis of the interviews it turned out that - besides maintaining community traditions and mutual help for everyday life in Chicago - the main reason for migrants to become members of a hometown association is to organize projects that support their communities of origin (such as renovating the local church, building streets, or constructing schools, mostly funded by the $3 x 1$ program of the Mexican government). ${ }^{2}$ Through such support

2 In order to include migrant issues in its political agenda, the Mexican government created the $3 \mathrm{xl}$ Program in 2002. The program today includes infrastructure projects (for example the reconstruction of public plazas and the paving of streets), social projects (for example the granting of students' [continues] 
activities, Michoacano migrants became involved in transnational action, as the Fedecmi-member Berenice relates:

"It is the place where you were born, it's your homeland. Although you leave your country, whether your situation is good or not, you always have nostalgic memories of your childhood, of the friendships you left behind, of a big part of your life you left behind. Well, maybe a way of giving back a little of what you received from your country is by building up relationships and by starting to help... like the 3xl Program, helping your home communities... And, then, the sentiment of the place where you belong always persists. Although you made a life here, it's not ours. It doesn't belong to us" [Berenice, Chicago, 30 March 2005].

This quote indicates that for activists, the strong bond to their community of origin drives their involvement in transnational projects. The feeling of not-entirely-belonging to US society strengthens this identification. For most Mexicans, migration to the United States is associated with cultural, economic and political experiences of exclusion - at least in the first years after arrival. Studies of Mexican migrants show that the sense of belonging to a community or region of origin often intensifies in migration and motivates transnational engagement (Besserer 1999: 21 8; Fox and Rivera-Salgado 2004: 1 1-13; Kearney 1988, 1995; Velasco Ortiz 2008). For Mexican migrants in Chicago, being members of a migrant organization means being publicly recognized as part of a local "we-group." This feeling is particularly important in the context of migration, as membership in a club, a federation or a local group of a Mexican political party restores their sense of proximity to the community and country of origin they left behind and creates a new sense of belonging.

Nevertheless, Mexican migrant organizations are not only oriented to support activities in their country of origin, but also have a strong local attachment to their places of residence in the United States, as shown by Casa Michoacán, the headquarters of the Michoacano federation, Fedecmi, in Chicago's Pilsen neighborhood. It has become a very important place for Mexican migrants in the city: as a referral center to assist migrants in their daily life in Chicago and obtain public services (from food stamps to unemployment to free health care access) and educational training (such as computer courses). Also, it is a place of civic engagement: for example, the big marches for comprehensive immigration reform were organized in Casa Michoacán in 2006. Other federations 
have similar cultural centers in Chicago, such as Centro Cultural Zacatecano, Casa Jalisco and Casa Chilanga (from Mexico City).

As we have seen, we are confronted with very territorial concepts of local space, such as the home communities and Casa Michoacán in the neighborhood of Pilsen, where the large majority of the population is of Mexican origin. ${ }^{3}$ At the same time, the practices of the hometown associations cross and transcend territorial notions of space. For example, the founding of hometown associations in Chicago has a direct territorial dimension because the associations refer to the community of origin. At the same time these groups deterritorialize the community by reorganizing it in Chicago.

At once, hometown associations are both attached to a concrete place (the home community, Casa Michoacán) and transterritorial (as Mexico in Chicago or Chicago in Mexico). According to Arjun Appadurai, locality is produced in concrete life situations in which actors are interwoven (Appadurai 1996). Here locality is produced not only in territorially specific locations, but also in transnational communities formed by social relationships (kinship and friendship) maintained among migrants and members of their communities of origin. In the transnational context "the local" must be understood as a space of social relationships. Although these social relationships are not located in one specific place, they refer to specific local contexts, such as the communities in Michoacán and the Mexican neighborhood of Pilsen in Chicago.

\section{THE DEVELOPMENT OF AGENCY}

Based on their local and transnational social relationship networks as well as on their organization in hometown associations and federations, Mexican migrant activists develop new social agency. Laura Velasco Ortiz shows how migrants combine experiences they gain by migrating with cultural and social knowledge learned in their communities of origin (Velasco Ortiz 1998: 111, 126). The transnational agency of migrant activists is based on social, political and symbolic capital and transcultural competence developed in two national contexts. Leaders of Chicago hometown associations and federations accumulate social capital in negotiating with Mexican government authorities for collective projects, which they can then convert to "agency." The role of these leaders in transnational negotiation processes and their biographical narratives show that creative social and political learning processes are part of the transnationalization of "the political," as the example of Artemio shows.

3 Between the mid- $19^{\text {th }}$ and early $20^{\text {th }}$ century, neighborhoods such as Pilsen, Little Italy and Greektown - all founded by European immigrants - developed in Chicago and were called "ethnic neighborhoods." Today, the population of many of these neighborhoods, such as Pilsen and Little Italy, is predominantly of Mexican origin. 
Artemio, along with family members and friends, founded Chicago's Club Acuitzio del Canje in the 1990s, which then became one of the founding members of Fedecmi. From the beginning, Artemio's interest in founding Fedecmi was to increase political leverage and negotiate with Mexican governments for financial support of community projects. The Fedecmi network helped him carry out projects in his community. Yet Artemio has managed to expand his political capital and influence events far beyond his community: as a leading member of Fedecmi he has developed contacts that extend into Michoacán state politics. When it comes to carrying out projects, he uses his political relationships:

"I arranged the reconstruction of the road from Acuitzio del Canje to Canoas for them through my contacts and my congressmen friends. I arranged the financial support; the municipality didn't have to do anything. So, when I'm able to do certain things, I move ahead on my own. But sometimes I could do more and I don't, because every one of those things also requires commitments in return. I have to spend money, time and effort" [Artemio, Chicago, 25 March 2005].

Because of his contacts with state government officials, Artemio was able to organize support projects in his community. The political capital that Artemio acquired through his work in the federation opened doors to US political circles. Today, Artemio is the political director of the US-civic organization Illinois Coalition for Immigrant and Refugee Rights (ICIRR) ${ }^{4}$ and his political agenda is directed at the vindication of migrant rights in the US. Prior to this important new position, he was one of the main organizers of mass demonstrations for comprehensive immigration legislation in Chicago and California in 2006. After that he worked as a spokesperson for the Latino press during Barack Obama's 2008 presidential campaign. Artemio sees his career as a logical political development:

"This has been a slow, but very noticeable, very significant process, because first I focused more on creating a structure of clubs and federations with an agenda for Mexico. Now the same people are still on my agenda, but the focus is on the US, and that doesn't mean that I forget things back there. But now the priority is here, the priority is immigration reform; the priority is to acquire power so our people live better here" [Artemio, Chicago, 10 July 2009].

Artemio's political success on both sides of the border is closely interconnected. His success is derived from the reciprocal application of knowledge and influence acquired in both political arenas. As his political contacts extend 
to the state level in Michoacán, he uses this position to apply for community projects. His position as a leading member of Fedecmi and as a successful organizer of community projects later helped him to expand his influence in the US political arena.

By participating in a migrant organization activists develop new skills: the ability to speak in front of others, to represent an opinion, to plan activities, to make decisions, to develop ideas and to act as a representative of a group. In relation to Mexico, the newly acquired agency of the migrant leaders means the ability to negotiate projects, to act as spokesperson and to obtain respect and recognition. In Mexico, these leaders have the role of benefactors who promote education, health and the modernization of the communities' infrastructure. They have a special position as expatriate nationals: they cannot be directly controlled by the Mexican state. They are therefore free to act beyond state and municipal control in different arenas and at different political and institutional levels. Leaders who come from lower-class and lower middle-class communities in Mexico are now in contact with high-ranking politicians and representatives, from both Mexico and the United States. They sit with them at the same table and invite them to the celebrations of their hometown associations and federations; that is, through their support work in the communities of origin they gain access to institutional level politics. Through the agency that migrant leaders develop in negotiations with their home communities and Mexican government bodies, they also acquire agency regarding US politics: when interacting with US government officials, politicians and civic organization leaders, they play the role of successful immigrants who are willing to learn and act as spokespersons for their community. The appointment of Artemio as political director of ICIRR shows the agency that the Mexican migrant community has gained in the US political scene.

Chicago's Mexican migrant leaders act as brokers between various local actors (for example between migrants and their communities of origin), between Mexican governments and migrant organizations (between hometown associations, communities of origin and municipal governments), between migrant organizations and US government institutions, between political parties and civic organizations as well as between different political cultures. It is precisely from transcultural mediation and transnational linking of different overlapping interaction and communication arenas that they develop agency (Anzaldúa 1987; Brah 1996).

\section{POLITICAL ACTION IN AND BEYOND NATION-STATE STRUCTURES}

At the same time Mexican migrant organizations and their leaders act beyond and within national state structures. In the interviews, activists from Chicago give insight as to how the political action of Mexican migrant organizations 
not only takes place in a transnational context beyond nation-states, but must also be considered within national political structures. The case of migrant leader Artemio highlights how they broaden their activities to interaction and communication arenas that involve different sub-national (local, municipal and state) and national levels of government. Based on their position in the communities of origin and municipalities, migrant leaders have successfully gained access to state and federal government levels in Mexico. In the United States, migrant leaders gained access to state and federal policy arenas based on the local positioning of migrant organizations in Pilsen and in Chicago's other Mexican neighborhoods. Based on the following three examples, I show how political action takes place in nation-state structures and transcends them at the same time.

\section{Representing Mexico from abroad}

Mexican migrant activists demand political participation and representation in Mexico's political system. They legitimize their demands in several ways: their rights as Mexican citizens, their role as migrants who had to leave their country and build a new life in the United States, their economic support of the communities of origin as well as their sense of belonging to a community of origin. For these efforts and sacrifices they demand respect and access to political representation in state and national level politics, for example, as representatives in the Mexican Federal Congress or in one of the state congresses.

Initially, Chicago's migrant leaders became involved with Mexican parties to fight for the right to vote from abroad. As a result, they were able to vote in Mexican presidential elections in 2006 and 2012. Now their demands go further as migrant leader Fabián explains:

"What we're looking for, is to continue living here and to be able to go to San Lazaro, to Congress, whenever it's necessary to make decisions that affect our people here and also their families in their hometowns. What we're looking to do is to be congressmen. We want to represent immigrants from outside Mexico, because we're the only ones who know our needs. There are other congressmen who represent us, but they've never been immigrants. The migrant should be able to represent himself. I think migrants are owed that respect" [Fabián, Chicago, 22 June 2009].

For Fabián, the right to be represented in Mexico has to do with respect that migrants deserve because they had to leave their country due to the difficult economic circumstances while still supporting their home regions. For the migrant leaders, it is very important "to be respected" as a recognition of their sacrifices in migrating and their efforts in organizing support projects in their home communities. They claim the right to represent Mexican migrants at 
the federal level in Mexico and to run their own candidates for congressional seats. They propose that the entire territory of the US should be recognized as a sixth constituency (circunscripción electoral) in Mexican presidential elections with the corresponding number of seats in San Lázaro, the Mexican Federal Congress (Mexico is currently divided into five electoral constituencies; each constituency has 40 seats for congressmen).

That is, on the one hand, migrant activists call for inclusion and recognition within the nation-state structures; on the other hand, their demands mean a delimitation of national-state structures according to a conventional understanding of citizenship and political representation within territorial boundaries. Their demand for migrant representation in the Mexican federal congress goes beyond the conventional understanding of democracy as a government territorially bounded to the limits of the nation-state.

\section{Transnational negotiating within the 3xl Program}

The Mexican government's 3xl Program is another clear example of simultaneous inclusion in nation-state structures and delimitation in the transnational context. The procedure for funding the program is as follows: migrant hometown associations suggest a project and assume responsibility for a quarter of the financing; then they negotiate with Mexican government entities at the municipal, state, and national levels for co-financing. My empirical results, however, also show that the $3 \mathrm{xl}$ projects do not always follow this procedure, but that the projects are negotiated in transnational arenas due to different local and regional power structures.

A good example is the case of Francisco Villa, a community of about 1200 inhabitants in the municipality of Zinapecuaro in northern Michoacán. A third of the "inhabitants" live in Chicago most of the year. In Chicago, migrants from Francisco Villa are organized in a hometown association, which has also been part of the federation Fedecmi since 2003. The members founded the hometown association with the idea of improving infrastructure and social services in their community. After they had joined Fedecmi, the members of Club Francisco Villa learned that it was possible to obtain financial support through the 3xl Program, and in 2002 it became one of the first hometown associations to apply for a project. However, the municipal government of Zinapecuaro refused to contribute its share of the funding. The Partido Revolucionario Institucional (PRI) had been in power in the municipality since the end of the Mexican Revolution (1910-17), when municipal governments were first elected. Since the current municipal government (2002-04) would not collaborate with them, in subsequent elections the migrant hometown association supported the campaign of a young man from their community who was a member of the left-leaning opposition party, the Partido de la Revolución Democrática (PRD). The candidate, Raúl, relates: 
"So, again, the municipal government did not participate, and so, when the campaigns came in 2004, and the possibility arose for me to participate, the migrants got together and they told me, you know what? We want to support you, because we want someone to help us to do some more work in the community. So, Rubén and a group of many more people started to support me, they gathered financial support for the campaign, which totaled nearly 15,000 dollars. Look, this is really generous, because they cannot vote here, but they can pick up the telephone and say, look, mom, dad, there will be elections and, look, we are offering our money to do some work in the community, so please help us so that Raúl can win. So that helped, from the US they moved something. So, I won like never in the history of Zinapecuaro before, it was something overwhelming, and historic. So, when I won that election, my commitment was to help the migrants, to work with them. When we came to the municipal presidency, we designated five million pesos exclusively (about 380,000 dollars) to the 3xl Program" [Raúl, 3 January 2009].

In the municipality of Zinapecuaro, which has about 48,000 inhabitants, a change of government took place because of strong migrant leadership in one of the smallest communities of the municipality. This example demonstrates how migrants influence local decision-making processes through cross-border networking of political relationships. Once the new municipal president from Zinapecuaro (2005-08) was elected, the migrants immediately negotiated with him regarding several projects within the framework of the 3xl Program. Besides the construction of a middle school, the paving of almost all the roads of the community, and the renovation of the community's central square, the most significant project consisted of building several greenhouses for growing tomatoes. In this project the migrant group in Chicago and the community of Francisco Villa are jointly engaged as business partners. The migrant group of Club Francisco Villa was able to expand its newly acquired influence on the term of office of the next municipal president of Zinapecuaro, who had been a member of his predecessor's team.

As we can see from the example of Francisco Villa, migrants influence local elections through their financial support and through their social capital, that is, their family and friendship relationships. This demonstrates how the social reality of Michoacano municipalities has moved beyond the Mexican constitution to accommodate transnational political spaces. Although, officially, fundraising abroad for municipal campaigns is illegal, as is the election of a migrant with dual nationality to municipal government office, there is empirical evidence that shows that the transnational reality of many municipalities in Michoacán has superseded national law, as a former member of the government of Michoacán attests: 
"From 2002 to 2004, 32 per cent of the municipal presidents in Michoacán were migrants, some even had dual nationality, which is a thing that is contrary to Mexican legislation - the occupation of a publicly elected position" [former state coordinator for migrant affairs, 4 December 2008].

\section{Transnationalizing Mexican political parties}

The same dual phenomenon - the direct reference to government politics, on the one hand, and the simultaneous embedding in transnational political contexts, on the other - can also be observed in the local groups of the three major Mexican parties founded since the mid-1990s. The activities of these groups not only relate to the Mexican nation-state, but also achieve their own transnational significance through representation of Mexican migrants in Chicago. For example, during Chicago's city council elections, the Mexican-born local politician and member of the Democratic Party, Danny Solís, perceived his competitor primarily as a representative of the Mexican PRD and not as another candidate of the Democratic Party of the United States. Danny Solís was elected to Chicago's City Council as alderman from the $25^{\text {th }}$ Ward (its main neighborhood is Pilsen) against another Mexican-born Democratic candidate, who is also a member of the PRD-Chicago. Jorge remembers what happened when Solís won the elections:

"Two years ago in the municipal elections of Chicago, the first public statement of alderman Danny Solís was: 'We defeated the PRD!' Because that's how he saw it. He perceived that the candidate who was against him was from the PRD, that the PRD was campaigning against Danny Solís in the city of Chicago. Now it's not just our perception anymore, it's the perception of a Chicago official" [Jorge, Chicago, 22 July 2009].

Danny Solís started his political career as a community leader in Pilsen. ${ }^{5}$ What distinguishes him from the Mexican migrant leaders is that he grew up and was socialized in the US. It is particularly interesting to see that he did not associate his political challenger with the Democratic Party, the party he represented in the City Council's election, but instead with the PRD. This association was not caused by actual Mexican interference in a US municipal election, but instead has its roots in Mexican political symbolism that receives transnational function and significance within a US election. Other Mexican American politicians identify themselves explicitly with Mexican parties, such

5 Chicago politician Danny Solís was born in Monterrey, Mexico, and came to Chicago as a child. He graduated from high school, studied at the University of Illinois at Chicago, and first became elected as alderman of the Chicago City Council in 1996. 
as US-born Illinois state senator Martín Sandoval. ${ }^{6}$ Similar to Danny Solís, Martín Sandoval was politicized within civic organizations in Mexican neighborhoods and feels deeply connected to them. Jorge explains his party affiliation in the transnational context:

"You live with two nationalities, two citizenships, one foot on each side of the border. Senator Sandoval, Illinois state senator, declared himself as a PRD member and went to his state of origin, Guerrero, to campaign for the PRD. In a public PRD event here he said, 'I was elected to represent Mexicans and then I represent the interests of the Mexicans of Illinois in Guerrero'” [Jorge, Chicago, 22 July 2009].

This quote demonstrates the increasing transnational orientation of Mexican political parties and their representation on both sides of the border: not only do Mexican party politicians visit Chicago to promote their political program and to expand their membership, but US politicians of Mexican origin also travel to Mexico to represent Mexicans from Illinois.

\section{THE INTERTWINING OF MULTIFACETED INTERACTION}

\section{AND COMMUNICATION ARENAS}

My study shows that the intertwining of different interaction and communication arenas is basic for the establishment of transnational political spaces and the public visibility of Mexican migrants' political involvement. As already mentioned, I understand these arenas as specific locations and at the same time as dense networks of political interaction and communication (Strauss 1993; Turner 1974). In these arenas, interaction and communication between the migrant community and actors from their home communities, government bodies, political parties and civic organizations take place. Here activities, concerns, and the actors' networks are intertwined. The arenas emerge especially in the mobilization of social movements, in the planning of transnational support projects and in the negotiation of demands with government authorities in both countries. They manifest themselves in several ways: at specific locations, in social relationships, in socio-political arrangements and in different organizational structures. Below I would like to mention some of these arenas.

First, they are concrete locations of Mexican migrant organizations' political activities in Chicago: meeting places such as Casa Michoacán, which has become a center for political activities of the Mexican migrant community 
in Chicago. Another meeting place is Casa Aztlán - a few street blocks away from Casa Michoacán and also in the Pilsen neighborhood. Casa Aztlán is a community center that provides support for Mexican migrants in the areas of education, health and other social services. Second, local arenas develop in negotiating processes, for example within the 3xl Program. The program envisions that migrant organizations propose support projects for their communities of origin, and then negotiate with the respective municipality as well as with the state and federal governments for financing. In the negotiation processes of the 3xl Program most activists first come in direct contact with Mexican government representatives; the skills learned here then can be applied in other arenas. The example of the community of Francisco Villa shows that the negotiation processes in transnational arenas were decisive for the successful implementation of the $3 x \mathrm{l}$ projects. Thirdly, arenas arise in social and political movements. In the movement for the right to vote from abroad Mexican migrant organizations in Chicago and across the United States united for the first time: federations as well as the local groups affiliated with Mexican political parties participated. The migrant organizations were able to build on this already existing network when a new challenge appeared in the form of restrictive US immigration legislation. At the beginning of 2006 a new arena developed to organize the Chicago migrant community's protest movement in Casa Michoacán.

The arenas described above are not separate political spaces, but are linked together by transnationalization processes and that is precisely how they earn political significance. The results of my study show that Mexican migrant community leaders bundle their newly acquired skills of political representation, negotiation and action in different arenas. They manage to transfer the social and symbolic capital that they have acquired in one arena (centered on Mexican politics), and are able to transfer it to other arenas (which are focused on different arenas in US politics).

\section{CONCLUSIONS}

Mexican migrants in Chicago have developed fixed locations, networks and organizations for interaction and communication arenas. They have established transnational organizations, negotiate at the local, state and federal government levels and are visible in the context of civic organization in two countries. The analysis of my interview data shows that, through their multifaceted social and political engagement, Mexican migrant activists link organizational forms, movements and issues in cross-border political interaction and communication arenas, thereby creating new transnational political spaces: first, they engage in hometown associations (community-level, civic) and federations (state-level, civic) to organize infrastructure and support projects for 
their communities of origin; second, they demand political and civic rights for migrants as members of local Mexican party groups and as representatives of US civic organizations (such as the Illinois Coalition for Immigrant and Refugee Rights).

The four characteristics discussed above are central for the understanding of transnational political spaces: "the local" as network of social relationships; political action in and beyond nation-state structures; the development of agency; and the intertwining of multifaceted interaction and communication arenas. They are central to the study of transnationalism processes that do not take place at the institutional level (for example between international organizations), but are constructed by local actors through their networks of relationships and membership in various forms of organizations. However, the locally-motivated transnationalization processes do not remain at the micro level. Through the intervention of local actors (of migrant organizations) in institutional politics (governments, parties) and of politicians in the arenas and projects of migrant organizations, these are transformed: local initiatives, which constitute political arenas of interaction and communication, develop into transnational spaces of organized political activities.

\section{REFERENCES}

ANZALDÚA, Gloria, 1987, The Border/La Frontera: The New Mestiza. San Francisco, Aunt Lute Books.

APPADURAI, Arjun, 1996, Modernity at Large: Cultural Dimensions of Globalization. Minneapolis and London, University of Minnesota Press.

BADA, Xóchitl, 2008, Sociopolitical Remittances, Rural Development, and Mexican Migrant Hometown Associations: The Shifting Nature of Transnational and Trans-Local Connections in the Chicago-Michoacán Corridor. Notre Dame, IN, University of Notre Dame, PhD dissertation.

BADA, Xóchitl, 2013, "From national to topophilic attachments: continuities and changes in Chicago's Mexican migrant organizations", Latino Studies, 11 (1): 28-54.

BADA, Xóchitl, Jonathan FOX, and Andrew SEELE (eds.), 2006, Al Fin Visibles: La Presencia

Cívica de los Migrantes Mexicanos en Estados Unidos. Washington, DC, Woodrow Wilson International Center for Scholars.

BADillo moreno, Gonzalo (ed.), 2004, El Voto de los Mexicanos en el Extranjero: Documentos.

Morelia, Gobierno del Estado de Michoacán.

BASCH, Linda, Nina GLICK SCHILlER, and Cristina SZANTON BLANC, 1994, Nations

Unbound: Transnational Projects, Postcolonial Predicaments and Deterritorialized Nation-States.

London, Routledge. 
BESSERER, Federico, 1999, "Estudios transnacionales y ciudadanía transnacional”, in Gail Mummert (ed.), Fronteras Fragmentadas. Zamora, Colegio de Michoacán and CIDEM, 215-238.

BORUCHOFF, Judith A., 2013a, "Special section introduction: transnational engagement of Mexican migrant organizations in Chicago", Latino Studies, 11 (1): 21-27.

BORUCHOFF, Judith A., 2013b, "From public works to political actions: Political socialization in Guerrero hometown organizations", Latino Studies, 11 (1): 55-77.

BRAH, Avtar, 1996, Cartographies of Diaspora: Contesting Identities. New York and London, Routledge.

BROOKS, David, and Jonathan FOX (eds.), 2002, Cross-Border Dialogues: US-Mexico Social Movements Networking. La Jolla, CA, Center for US-Mexican Studies, University of California San Diego.

CAlderón CHEliUS, Leticia (ed.), 2003, Votar en la Distancia: La Extensión de los Derechos Políticos a Migrantes, Experiencias Comparadas. México, DF, Instituto de Investigaciones Dr. José María Luis Mora.

CALDERÓn CHELIUS, Leticia, 2011 1, Los Superheroes No Existen: Los Migrantes Mexicanos ante las Primeras Elecciones en el Exterior. México, DF, Instituto de Investigaciones Dr. José María Luis Mora.

ESCALA RABADÁN, Luis, 2005, "Migración internacional y organizaciones de migrantes en regiones emergentes: el caso de Hidalgo", Migración y Desarrollo, 1: 66-88.

FAIST, Thomas, 2006, The Transnational Social Spaces of Migration. Bielefeld, Comcad (Center on Migration, Citizenship and Development), Working Paper \# 10.

FLORES-GONZÁLEZ, Nilda, and Amalia PALLARES (eds.), 2010, iMarcha! Latino Chicago and the Immigrant Rights Movement. Champaign, University of Illinois Press.

FOX, Jonathan, and Gaspar RIVERA-SALGADO (eds.), 2004, Indigenous Mexican Migrants in the United States. La Jolla, CA, Center for US-Mexican Studies and Center for Comparative Immigration Studies, University of California San Diego.

GOLDRING, Luin, 1998, "The power of status in transnational social fields", in Michael Peter Smith and Luis Eduardo Guarnizo (eds.), Transnationalism from Below. New Brunswick, Transaction Publishers, 165-195.

GOLDRING, Luin, 2001, "The gender and geography of citizenship in Mexico-US transnational spaces", Identities, 7: 501-537.

KEARNEY, Michael, 1988, "Mixtec political consciousness: from passive to active resistance", in Daniel Nugent (ed.), Rural Revolt in Mexico and US Intervention. La Jolla, CA, Center for US-Mexico Studies, University of California San Diego, 113-124.

KEARNEY, Michael, 1995, "The effects of transnational culture, economy, and migration on Mixtec identity in Oaxacalifornia", in Michael P. Smith and Joe R. Feagin (eds.), The Bubbling Cauldron: Race, Ethnicity, and the Urban Crisis. Minneapolis, University of Minnesota Press, 226-243.

KHAGRAM, Sanjeev, and Peggy LEVITT, 2008, The Transnational Studies Reader: Intersections and Innovations. New York and London, Routledge.

LEVITT, Peggy, and Nina GLICK SCHILLER, 2004, "Conceptualizing simultaneity: a transnational social field perspective on society”, International Migration Review, 38 (3): 1002 $-1039$.

LEWEllen, Ted C., 2003, Political Anthropology: An Introduction. Westport and London, Praeger Publishers. 
LÓPeZ CASTro, Gustavo, 2003, Diáspora Michoacana. México, DF, El Colegio de Michoacán and Gobierno del Estado de Michoacán.

MOCTEZUMA LONGORIA, Miguel, 2003, "Territorialidad socio-cultural y política de los clubes zacatecanos en Estados Unidos”, Migración y Desarrollo, 1: 1-25.

PRIES, Ludger, 1996, “Transnationale soziale Räume: theoretisch-empirische Skizze am Beispiel der Arbeitswanderungen Mexico-USA”, Zeitschrift für Soziologie, 25 (6): 456-472. PRIES, Ludger, 2010, Transnationalisierung: Theorie und Empirie grenzüberschreitender Vergesellschaftung. Wiesbaden, VS Verlag.

RIVERA-SALGADO, Gaspar, 2002, "Cross-border grassroots organizations", in David Brooks and Jonathan Fox (eds.), Cross-Border Dialogues: US-Mexico Social Movements Networking. La Jolla, CA, Center for US-Mexican Studies, University of California San Diego, 259-274 .

SCHÜTZE, Stephanie, 2013, "Chicago/Michoacán: The construction of transnational political spaces”, Latino Studies, 11 (1): 78-102.

SCHÜTZE, Stephanie, 2016, Constructing Transnational Political Spaces: The Multifaceted Political Engagement of Mexican Migrants between Chicago and Michoacán. New York, Palgrave Macmillan.

SMITH, Michael Peter, and Luis Eduardo GUARNIZO, 1998, Transnationalism from Below. New Brunswick, Transaction Publishers.

STRAUSS, Anselm, 1993, Continual Permutations of Action. New York, Aldine Transaction.

SWARTZ, Marc J., Victor W. TURNER, and Arthur TUDEN (eds.), 1966, Political Anthropology. New York, Aldine Publishing Company.

TURNER, Victor, 1974, Dramas, Fields and Metaphors: Symbolic Action in Human Society. Ithaca, Cornell University Press.

VELASCO ORTIZ, Laura, 1998, "Identidad cultural y territorio: una reflexión en torno a las comunidades transnacionales entre México y Estados Unidos”, Región y Sociedad, IX (15): 105-130.

VELASCO ORTIZ, Laura (ed.), 2008, Migración, Fronteras e Identidades Étnicas Transnacionales. Tijuana, BC, El Colegio de la Frontera Norte.

VERTOVEC, Steven, 2009, Transnationalism. London and New York, Routledge.

ZAMUDIO GRAV, Patricia, 2005, "¿El señor o la señora? Gender and participation in Chicago's Mexican immigrant community”, Journal of the Illinois State Historical Society, 98: 184-203.

Receção da versão original / Original version

Receção da versão revista / Revised version

Aceitação / Accepted
$2016 / 11 / 26$

$2018 / 02 / 02$

$2018 / 02 / 28$ 